\title{
EFFECTS OF METEOROLOGICAL CONDITIONS ON THE GROWTH AND SURVIVAL OF YOUNG PEREGRINE FALCONS
}

\author{
Alexandre Anctil ${ }^{1}$, Alastair Franke ${ }^{2}$, Poisey Alogut ${ }^{3}$, and Joël Bêty ${ }^{1}$ \\ ${ }^{1}$ Département de Biologie, Université du Québec à Rimouski, C. P. 3300, succ. A, 300, Allée des \\ Ursulines, Rimouski, Québec G5L 3A1, Canada \\ ${ }^{2}$ Canadian Circumpolar Institute, University of Alberta, 1-42 Pembina Hall, \\ Edmonton, Alberta T6G $2 \mathrm{H} 8$, Canada \\ ${ }^{3}$ Arctic Raptor Project, Box 817, Rankin Inlet, Nunavut, Canada
}

\begin{abstract}
One of the many challenges that climate change researchers are facing is predicting how animal populations may respond to changes in environmental conditions. Changes in climatic patterns may affect populations directly (e.g., influencing thermoregulation of individuals) or indirectly (e.g., influencing food availability). We investigated how those two types of effects affected the growth and survival of Peregrine Falcon (Falco peregrinus) nestlings in the Arctic.
\end{abstract}

Our study area is located on the west shore of Hudson Bay, around the community of Rankin Inlet, Nunavut $\left(62^{\circ} \mathrm{N}, 92^{\circ} \mathrm{W}\right)$, where the average summer temperature increased by approximately 1.5 degrees between 1982 and 2009. Here, a long-term studied Peregrine Falcon population shows a highly variable annual productivity that seems to be correlated with the amount of summer precipitation. To examine the effect of precipitation on the growth and survival of the young Peregrine Falcons, we used a combination of nest boxes, automatic scouting cameras and portable weather stations. During the summers of 2009 and 2010, we systematically followed 34 nests, on 12 of which we deployed nest boxes, hence protecting the chicks from the rain and the wind. We then followed chick survival and growth rate at protected sites and unprotected sites. Cameras allowed us to determine changes in food delivery from the parents during storms as well as to determine the causes of mortality of the chicks.

Preliminary results show that chicks raised at protected sites tended to survive better than chicks at unprotected sites. However, the growth rate of the surviving chicks did not seem to be affected. The cameras showed that food delivery diminished (sometimes by half) during extended periods of rain. These results indicate that both the direct and indirect effects of weather can strongly affect the condition of the young Peregrine Falcons. An understanding of how changes in weather, like an increase in precipitation, can affect animal populations is critical. These findings provide insight into the influence of changing weather pattern on arctic-nesting Peregrine Falcons. Received 30 October 2010, accepted 1 February 2011. 
Anctil, A., A. Franke, P. Alogut, And J. Bêty. 2011. Effects of meteorological conditions on the growth and survival of young Peregrine Falcons. Abstract, pages 323-324 in R. T. Watson, T. J. Cade, M. Fuller, G. Hunt, and E. Potapov (Eds.). Gyrfalcons and Ptarmigan in a Changing World, Volume II. The Peregrine Fund, Boise, Idaho, USA. http://dx.doi.org/ $10.4080 / \mathrm{gpcw} .2011 .0310$ 